\title{
Oestrogen action on thyroid progenitor cells: relevant for the pathogenesis of thyroid nodules?
}

\author{
Shuhang $\mathrm{Xu}^{+}$, Guofang Chen, Wen Peng, Kostja Renko ${ }^{1}$ and Michael Derwahl \\ Division of Endocrinology, Department of Medicine, St Hedwig Hospital and ${ }^{1}$ Institute for Experimental \\ Endocrinology, Charite, University Medicine, Grosse Hamburger Straße 5-11, D-10115 Berlin, Germany \\ ${ }^{\dagger}$ ( $\mathrm{X} \mathrm{X}$ is now at Endocrinology Department, Jiangsu Province Hospital on Integration of Chinese and Western \\ Medicine, Nanjing, China)
}

Correspondence should be addressed to M Derwahl

Email

m.derwahl@alexius.de; derwahl@ikfe-berlin.de

\begin{abstract}
Benign and malignant thyroid nodules are more prevalent in females than in males. Experimental data suggest that the proliferative effect of oestrogen rather than polymorphisms is responsible for this gender difference. This study analysed whether both differentiated thyroid cells and thyroid stem and progenitor cells are targets of oestrogen action. In thyroid stem/progenitor cells derived from nodular goitres, the ability of $17 \beta$-oestradiol $\left(E_{2}\right)$ to induce the formation of thyrospheres and the expression of oestrogen receptors (ERs) and the effect of $E_{2}$ on the growth and expression of markers of stem cells and thyroid differentiation (TSH receptor, thyroperoxidase, thyroglobulin and sodium iodide symporter (NIS)) were analysed. $\mathrm{E}_{2}$ induced thyrosphere formation, albeit to a lower extent than other growth factors. Thyroid stem and progenitor cells expressed ER $\alpha$ (ESR1) and $\operatorname{ER} \beta$ (ESR2) with eight times higher expression levels of ER $\alpha$ mRNA compared with the differentiated thyrocytes. $E_{2}$ was a potent stimulator of the growth of thyroid stem/progenitor cells. In contrast, TSH-induced differentiation of progenitor cells, in particular, the expression of NIS, was significantly inhibited by $E_{2}$. In conclusion, oestrogen stimulated the growth and simultaneously inhibited the differentiation of thyroid nodule-derived stem/progenitor cells. From these data and based on the concept of cellular heterogeneity, we hypothesize a supportive role of oestrogen in the propagation of thyroid stem/progenitor cells leading to the selection of a progeny of growth-prone cells with a decreased differentiation. These cells may be the origin of hypofunctioning or non-functioning thyroid nodules in females.
\end{abstract}

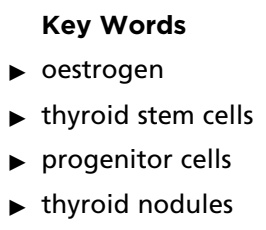

Journal of Endocrinology (2013) 218, 125-133

\section{Introduction}

Thyroid nodules are the most frequent endocrine neoplasms with three to four times higher prevalence in females than in males (Derwahl \& Studer 2002, Libutti 2005, Gharib et al. 2008). Their prevalence ranges from $4-7 \%$ palpable nodules to up to $60 \%$ when ultrasound is applied (Dean \& Gharib 2008).
The majority of these nodules are non-functioning, but only $5 \%$ of these scintigraphically 'cold' lesions are malignant tumours (Belfiore et al. 1992, Knudsen et al. 2000).

Understanding the pathogenesis of the different nodules may facilitate their diagnosis and enable a clear distinction between benign and malignant lesions.

Published by Bioscientifica Ltd 
However, although many pathogenetic factors such as iodine deficiency, mutagenesis, overexpression of growth factors and their related receptors, altered signalling, data on gene expression profiles and genetic predisposition are known, a comprehensive concept for the pathogenesis of thyroid nodules and nodular goitres is still missing (Studer \& Derwahl 1995, Krohn et al. 2005). At first glance, the high frequency of nodule formation in the thyroid gland is surprising because, compared with that of the highly proliferating tissues such as the colon and the breast, the growth rate of human thyroid cells is considerably lower with an estimated frequency of only about five cell divisions during adulthood (Coclet et al. 1989). However, tissues with a high cell turnover are more sensitive to mutagenesis and other molecular mechanisms that initiate tumour formation, whereas in resting tissues such as the thyroid gland, these mechanisms are less operative. To explain this discrepancy, it has been suggested that free radicals resulting from reactive oxygen species in the thyroid gland generate mutations more frequently (Maier et al. 2006).

Adult stem cells have been suggested as an alternative source of benign and malignant tumour formation (Reya et al. 2001, Fierabracci 2012). These cells reside in all tissues and organs and are capable of proliferating during the lifetime of the organism (Levi \& Morrison 2008). Stem cells have been identified in the human thyroid gland (Thomas et al. 2006, Lan et al. 2007, Fierabracci et al. 2008) and cancer stem cells in thyroid cancer cells and tissues (Mitsutake et al. 2007, Todaro et al. 2010, Zheng et al. 2010, Malaguarnera et al. 2011). Orthotopic transplantation of stem cells derived from undifferentiated thyroid cancer tissues into a mouse thyroid gland recapitulated the nature and behaviour of the original tumour, which supported the concept of stem cells being the source of tumour formation (Todaro et al. 2010, Derwahl 2011).

Besides epidemiological data on the higher prevalence of proliferative thyroid diseases in females, several experimental studies have provided evidence that oestrogen is involved in the pathogenesis of thyroid nodules and tumours. Benign and malignant thyroid cells and tissues express functional oestrogen receptors (ERs) and their growth is stimulated by oestrogen (Furlanetto et al. 1999, Manole et al. 2001, Ceresini et al. 2006, Kumar et al. 2010, Rajoria et al. 2010, Di Vito et al. 2011). In addition, the presence of these receptors has also been demonstrated in thyroid vessels that may be relevant for the vascularization of neoplastic tissues (Ceresini et al. 2006).

Herein, we report for the first time that thyroid stem and progenitor cells are also targets of oestrogen action. Compared with primary human thyroid cells, stem/progenitor cells expressed more than eight times higher $E R \alpha$ mRNA levels. 17 $\beta$-Oestradiol $\left(\mathrm{E}_{2}\right)$ promoted the growth of thyroid stem and progenitor cells and further up-regulated the expression of $E R \alpha$. Accordingly, the expression of cyclin D1 cells was significantly enhanced. $\mathrm{E}_{2}$ also promoted the formation of single stem cell-derived thyrospheres. On the other side, in response to $\mathrm{E}_{2}$ stimulation, the levels of thyroid differentiation markers such as TSHR, thyroid symporter peroxidase (TPO) and sodium iodide (NIS (SLC5A5)) were markedly decreased with a maximal inhibition of TSH-induced NIS expression.

In conclusion, oestrogen stimulated the growth and simultaneously inhibited the differentiation of thyroid nodule-derived stem/progenitor cells. From these data and based on the concept of cellular heterogeneity, we hypothesize a supportive role of oestrogen in the propagation of thyroid stem/progenitor cells that may lead to the selection of a progeny of growth-prone cells with a decreased differentiation. These cells may be the origin of hypofunctioning or non-functioning thyroid nodules in females.

\section{Materials and methods}

\section{Cell cultures and formation of thyrospheres}

Human thyrocytes and primary thyrospheres isolated from nodular goitres of 58 patients after thyroidectomy were cultured as described by our group previously (Lan et al. 2007). The mean age of the patients ( 40 females and 18 males) was $53.1 \pm 14.0$ years. Informed consent was obtained from all patients. The study was approved by the Ethics Committee of Charite, University Medicine Berlin.

For establishing the secondary generations of thyroid stem/progenitor cells (secondary thyrospheres), primary thyrospheres were dissociated mechanically and enzymatically into single cells and then cultured on poly-L-ornithine/fibronectin-coated (Sigma) dishes (cell density $10^{5}$ cells/ml) with DMEM/F12 (1:1, v/v; Invitrogen) containing B-27 (1:50; Invitrogen), epidermal growth factor (EGF, $20 \mathrm{ng} / \mathrm{ml}$; Invitrogen) and basic fibroblast growth factor (bFGF, $20 \mathrm{ng} / \mathrm{ml}$; Invitrogen).

\section{Conventional RT-PCR and real-time quantitative RT-PCR}

Total RNA was extracted using the RNeasy Micro Kit (Qiagen) according to the manufacturer's specifications. RT-PCR was performed as described previously (Broecker et al. 1998). Real-time quantitative RT-PCR was performed

Published by Bioscientifica Ltd. 
with the iCycler iQ Real-time PCR detector system (Bio-Rad), using the ABsolute QPCR SYBR Green Fluorescein Mix (Applied Thermo Fisher Scientific, Inc Schwerte, Germany.) according to the manufacturer's instructions. Cycling conditions were as follows: initial enzyme activation at $95^{\circ} \mathrm{C}$ for $15 \mathrm{~min}$, followed by 50 cycles at $95{ }^{\circ} \mathrm{C}$ for $15 \mathrm{~s}, 58^{\circ} \mathrm{C}$ for $30 \mathrm{~s}$ and $72{ }^{\circ} \mathrm{C}$ for $30 \mathrm{~s}$. The relative expression levels of each gene in real-time PCR were analysed using the $(2 \times \text { efficiency })^{-\Delta \Delta C t}$ method and normalized to the expression of the housekeeping gene $G A P D H$. Each sample was duplicated from independent sets of RNA preparations. The results are given as mean \pm S.E.M. of three independent experiments.

For all PCR analyses, GAPDH was used as an internal control. In addition, $18 S$ was used as a second housekeeping gene. Primer sequences, product sizes, cycle numbers and annealing temperatures are listed out in Table 1.

\section{5-Bromo-2'-deoxy-uridine incorporation}

The proliferative potential of secondary passaged human thyroid stem/progenitor cells was evaluated by 5-bromo-2'-deoxy-uridine (BrdU) incorporation using the BrdU Labelling and Detection Kit I (Roche). Human thyroid stem/progenitor cells, 8000-10 000 cells/well, were plated into 96-well microtitre plates pre-coated with poly-L-ornithine/fibronectin in phenol red-free DMEM/F12 medium. The cells underwent starvation and adhesion for $24 \mathrm{~h}$, and they were later incubated with $\mathrm{E}_{2}$ (0.1-100 nM, dissolved in a basal medium containing up to $0.13 \%$ ethanol; Sigma), B27, EGF and bFGF for $24 \mathrm{~h}$. For $\mathrm{E}_{2}$ stimulation experiments, the controls consisted of the basal medium with only the solvent. BrdU incorporation was performed according to the manufacturer's instructions.

\section{Immunofluorescence staining}

Coverslips were coated with $0.1 \mathrm{mg} / \mathrm{ml}$ poly-L-lysine (Sigma) before introducing the cells and the medium. Human secondary passaged stem/progenitor cells were plated on the coverslips and cultured in a medium containing B27, bFGF and EGF. After $24 \mathrm{~h}$, adhesive cells were rinsed with PBS, followed by fixation in pure

Table 1 Primer sequences, annealing temperatures, cycle numbers and product sizes for PCR

\begin{tabular}{|c|c|c|c|c|}
\hline Target gene & Primer sequences & $\begin{array}{l}\text { Annealing } \\
\text { temperature }\end{array}$ & Cycles & $\begin{array}{l}\text { Expected } \\
\text { size (bp) }\end{array}$ \\
\hline GAPDH & $\begin{array}{l}\text { S: 5'-GAAGGTGAAGGTCGGAGTC-3' } \\
\text { AS: 5'-GAAGATGGTGATGGGATTTC-3' }\end{array}$ & 58 & 26 & 226 \\
\hline$E R \alpha$ & $\begin{array}{l}\text { S: } 5^{\prime}-C C A C T C A A C A G C G T G T C T C-3^{\prime} \\
\text { AS: } 5^{\prime}-G G C A G A T T C C A T A G C C A T A C-3^{\prime}\end{array}$ & 58 & 36 & 243 \\
\hline$E R \beta$ & $\begin{array}{l}\text { S: 5'-CGCCAGTTATCACATCTGTATG-3' } \\
\text { AS: 5'-CCACTAACCTTCCTTTTCAGTG-3' }\end{array}$ & 58 & 36 & 112 \\
\hline NIS & $\begin{array}{l}\text { S: 5'-TCTCTCAGTCAACGCCTCT-3' } \\
\text { AS: 5'-ATCCAGGATGGCCACTTCTT-3' }\end{array}$ & 58 & 36 & 298 \\
\hline$T G$ & $\begin{array}{l}\text { S: 5'-GAGCCCTACCTCTTCTGGCA-3' } \\
\text { AS: 5'-ATCCAGGATGGCCACTTCTT-3' }\end{array}$ & 58 & 36 & 324 \\
\hline TSHR & $\begin{array}{l}\text { S: } 5^{\prime}-A G C C A C T G C T G T G C T T T T A A G-3^{\prime} \\
\text { AS: 5'-CCAAAACCAATGATCTCATCC- } 3^{\prime}\end{array}$ & 58 & 36 & 131 \\
\hline TPO & $\begin{array}{l}\text { S: 5'-GTCTGTCAGGCTGGTTATGG-3' } \\
\text { AS: 5'-CAATCACTCCGCTTGTTGGC-3' }\end{array}$ & 58 & 36 & 242 \\
\hline PAX8 & $\begin{array}{l}\text { S: 5'-TTTGCTTGGCTCTTTCTACACCTC-3' } \\
\text { AS: 5'-GAATGTCTGTTTTAAGCTCCCTGG-3' }\end{array}$ & 58 & 36 & 205 \\
\hline GATA4 ${ }^{\mathrm{a}}$ & $\begin{array}{l}\text { S: } 5^{\prime}-A C A A G A T G A A C G G C A T C A A C-3^{\prime} \\
\text { AS: } 5^{\prime}-C G T G G A G C T T C A T G T A G A G G-3^{\prime}\end{array}$ & 58 & & 174 \\
\hline GATA4 $4^{\mathrm{b}}$ & $\begin{array}{l}\text { S: } 5^{\prime}-C T C C T T C A G G C A G T G A G A G C-3^{\prime} \\
\text { AS: } 5^{\prime}-G A G A T G C A G T G T G C T C G T G C-3^{\prime}\end{array}$ & 58 & 36 & 575 \\
\hline OCT4 & $\begin{array}{l}\text { S: } 5^{\prime}-\text { GACAACAATGAGAACCTTCAGGAG-3' } \\
\text { AS: } 5^{\prime}-\text { CTGGCGCCGGTTACAGAACCA-3' }\end{array}$ & 55 & 30 & 216 \\
\hline Cyclin D1 ${ }^{\mathrm{a}}$ & $\begin{array}{l}\text { S: 5'-ACAAACAGATCATCCGCAAACAC-3' } \\
\text { AS: } 5^{\prime}-\text { TGTTGGGGCTCCTCAGGTTC-3' }\end{array}$ & 58 & 30 & 144 \\
\hline $18 S^{a}$ & $\begin{array}{l}\text { S: 5'-TTGACGGAAGGGCACCACCAG-3' } \\
\text { AS: 5'-GCACCACCACCCACGGAATCG-3' }\end{array}$ & 58 & & 130 \\
\hline \multicolumn{5}{|c|}{$\begin{array}{l}\text { S, sense primer; AS, antisense primer. } \\
\text { aOnly used for quantitative PCR. } \\
\text { bOnly used for conventional RT-PCR. }\end{array}$} \\
\hline $\begin{array}{l}\text { http://joe.endoc } \\
\text { DOI: } 10.1530 / J O\end{array}$ & $\begin{array}{r}\text { C } 2013 \text { Society for Endocrinology } \\
\text { Printed in Great Britain }\end{array}$ & & & \\
\hline
\end{tabular}


methanol at $-30{ }^{\circ} \mathrm{C}$ for $5 \mathrm{~min}$, permeabilized by $0.2 \%$ Triton X-100 for 10 min and then blocked by normal goat serum (10\%; Sigma) for $90 \mathrm{~min}$ at room temperature. The coverslips were incubated with the monoclonal anti-ER $\alpha$ (1:50) and polyclonal anti-ER $\beta$ (1:100) antibodies (both from Santa Cruz Biotechnology) at room temperature for $1 \mathrm{~h}$ and then at $4{ }^{\circ} \mathrm{C}$ overnight. Unbound antibodies were removed by rinsing with a washing buffer (PBS containing $0.1 \%$ Tween-20 and 1\% BSA), followed by incubation with FITC-conjugated secondary antibodies (1:400; Santa Cruz Biotechnology). FITC-labelled cells were analysed with a fluorescence Zeiss microscope using standard fluorescent filters (excitation $488 \mathrm{~nm}$ ).

\section{Statistical analysis}

Statistical analysis was performed using the SPSS Software version 13.0. Numerical data are expressed as mean \pm s.E.M. Statistical differences were considered significant at $P<0.05$.

\section{Results}

\section{$E_{2}$ had the potential to induce thyrosphere formation}

Primary human thyrospheres that were enriched with thyroid progenitor/stem cells (Lan et al. 2007) were dissociated and stimulated either with EGF $(20 \mathrm{ng} / \mathrm{ml})$ and bFGF $(20 \mathrm{ng} / \mathrm{ml})$ or with $1 \mathrm{nM} \mathrm{E}_{2}$. After 6 days of stimulation, secondary thyrospheres were reformed in both the groups. However, the size of the spheres formed in the $\mathrm{E}_{2}$ group was smaller than that of those formed in the group grown with growth factors (Fig. 1).

As revealed by the RT-PCR, the mRNA expression of the stem cell marker octamer transcription factor 4 (OCT4 (POU5F1)) was increased in the primary and secondary thyrospheres than in the primary thyrocytes. In contrast, the expression of NIS mRNA, a differentiation marker of thyroid follicular cells, was not detected in the primary and secondary thyrospheres (Fig. 2).

\section{ER $\alpha$ (ESR1) and ER $\beta$ (ESR2) mRNA expression and immunofluorescence staining in thyroid stem/progenitor cells derived from thyroid nodules}

Using RT-PCR, the expression of $E R \alpha$ and $E R \beta$ mRNAs was detected in both thyrocytes and thyrospheres with the expected amplicon sizes of 243 and 112 bp respectively. MCF-7 human breast cancer cells were used as a positive control (Fig. 3A). Quantitative PCR analysis
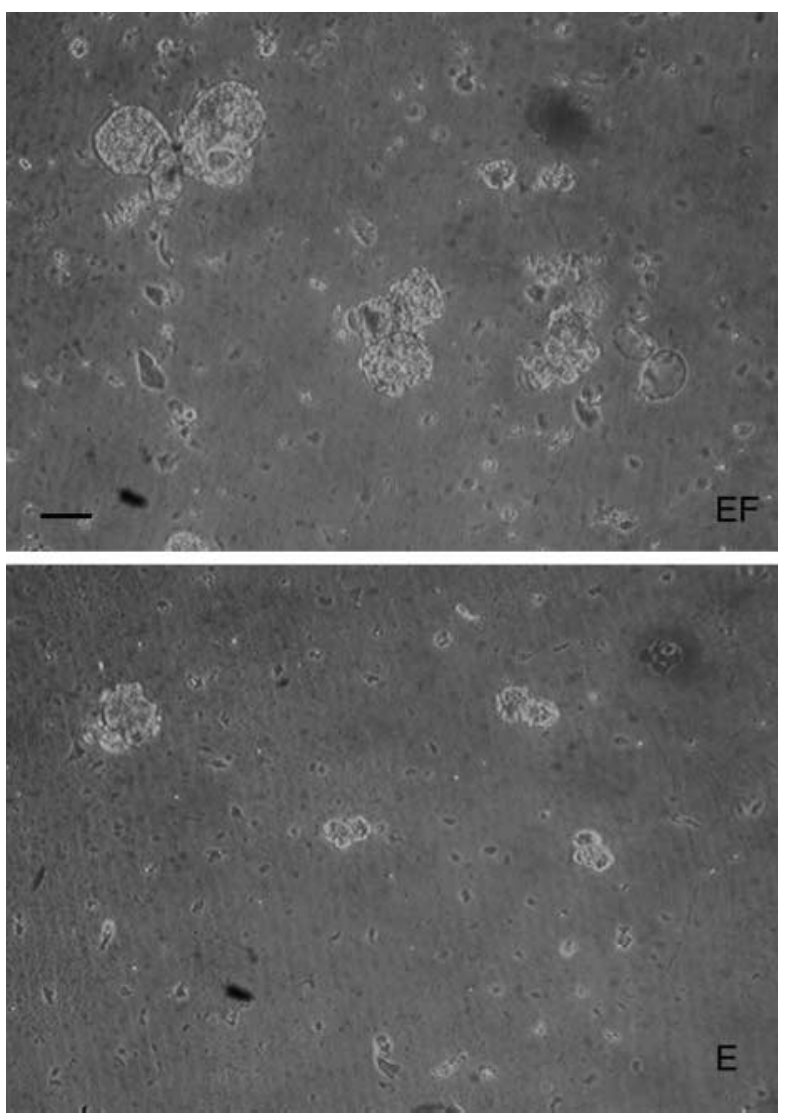

Figure 1

Thyrosphere formation was observed in both the groups with a smaller size of the spheres in the E2 group. Primary thyrospheres were dissociated and seeded in a serum-free DMEM/F12 medium with EGF $(20 \mathrm{ng} / \mathrm{ml})$ and bFGF $(20 \mathrm{ng} / \mathrm{ml})$ or with $1 \mathrm{nM}$ E2. EF, EGF and bFGF; E, E2. Scale bar: $100 \mathrm{~mm}$.

revealed an eightfold higher expression of $E R \alpha$ mRNA in the thyrospheres than in the thyrocytes $(8.85 \pm 0.81$ vs $\left.1.10 \pm 0.35,{ }^{* * *} P<0.001\right)$. No significant difference in the expression of $E R \beta$ mRNA was observed between the thyrospheres and thyrocytes (Fig. 3B).

By immunofluorescence staining, $\mathrm{ER} \alpha$ and $\operatorname{ER} \beta$ were detected in human thyroid stem/progenitor cells. Whereas $\mathrm{ER} \alpha$ was enriched in the nucleus, ER $\beta$ was located in the perinuclear region of the cytoplasm (Fig. 4A, B, C, D, E and $F$ ). This distribution of $E R \alpha$ and $E R \beta$ immunostaining corresponds to findings in breast cancer tissues (Jarzabek et al. 2005).

\section{$E_{2}$ increased BrdU incorporation into human thyroid progenitor/stem cells}

In a dose-dependent manner, $\mathrm{E}_{2}$ concentrations, ranging from 0.1 to $100 \mathrm{nM}$, increased BrdU incorporation into human thyroid progenitor/stem cells, with the maximum

Published by Bioscientifica Ltd. 


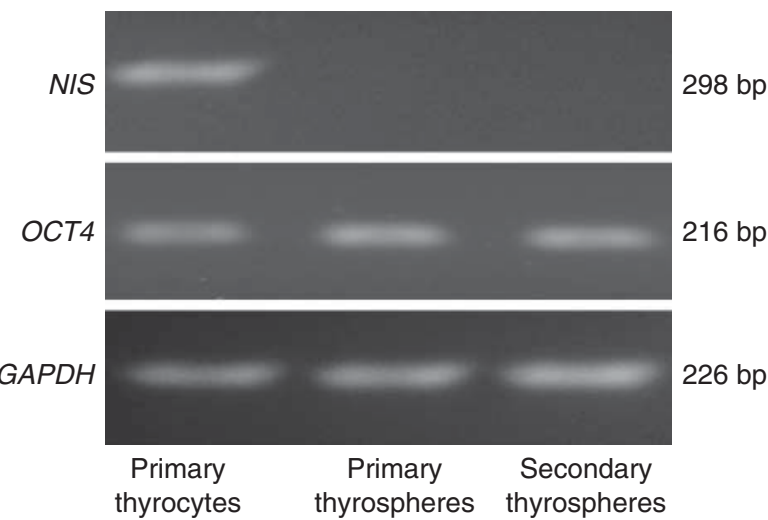

Figure 2

Expression of $\mathrm{Na}^{+} / \mathrm{I}^{-}$symporter (NIS) and OCT4 mRNAs in primary thyrocytes and primary and secondary thyrospheres. The expression of the stem cell marker OCT4 was increased in the primary and secondary passaged thyrospheres than in the thyrocytes, whereas that of the differentiation marker NIS was not detected in the thyrospheres. GAPDH was used as an internal control.

incorporation being observed at the concentration of $1 \mathrm{nM}(167.20 \pm 4.07 \%$ vs control, $P<0.01$; Fig. 5), showing a proliferative effect of $E_{2}$ on human thyroid stem/ progenitor cells.

\section{$E_{2}$ up-regulated the expression of $E R \alpha$ mRNA and enhanced the expression of cyclin D1 in human thyroid stem/progenitor cells}

After incubation with $1 \mathrm{nM} \mathrm{E}_{2}$ for $24 \mathrm{~h}$, the expression of ER $\alpha$ mRNA in human thyroid stem/progenitor cells was significantly increased by almost fivefold, whereas the expression of $E R \beta$ mRNA was not increased significantly (Fig. 6A).

Real-time PCR analysis revealed that the expression of cyclin D1 mRNA in human stem/progenitor cells was significantly increased $12 \mathrm{~h}$ after $1 \mathrm{nM} \mathrm{E}_{2}$ stimulation (Fig. 6B), which indicates that $\mathrm{E}_{2}$ is capable of upregulating the expression of cyclin $\mathrm{D} 1$, a main regulator of the cell cycle.

\section{$E_{2}$ decreased the expression of the differentiation markers}

To explore the effects of $\mathrm{E}_{2}$ and/or TSH on the differentiation of human thyroid progenitor cells, cell differentiation was induced using a medium with $10 \%$ serum and $5 \mathrm{mU} / \mathrm{ml}$ TSH for 3 days. The cells were further incubated with or without $\mathrm{E}_{2}$ for an additional 3 days, before the expression of the mRNA of thyroid differentiation markers (paired box gene 8 (PAX8), thyroglobulin
$(T g), N I S, T S H R$ and TPO) was analysed at day 6. A significantly decreased expression of the differentiation markers TSHR, NIS and TPO was observed, accompanied with an increased expression of the endodermal marker GATA4 (Fig. 7A).

\section{$E_{2}$ inhibited TSH-induced NIS expression}

To evaluate the effects of $\mathrm{E}_{2}$ on TSH-stimulated NIS expression, thyroid progenitor/stem cells were cultured with $10 \%$ serum and exposed to $1 \mathrm{nM} \mathrm{E}_{2}$ or/and $5 \mathrm{mU} / \mathrm{ml}$ TSH for 21 days. As expected, TSH significantly increased the expression of NIS mRNA (1.98 \pm 0.25 vs control, $P<0.01)$, whereas TSH-stimulated NIS expression was significantly suppressed by co-incubation with $1 \mathrm{nM} \mathrm{E}_{2}$ $(0.89 \pm 0.04$ vs $1.98 \pm 0.25, P<0.01$; Fig. 7B) .
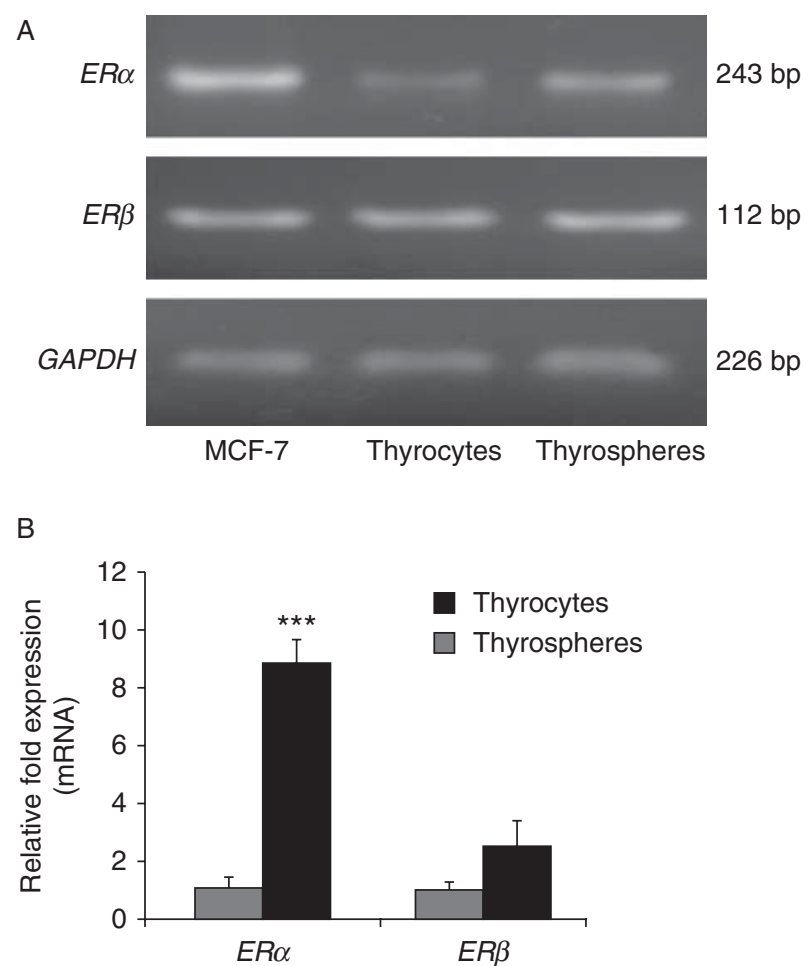

\section{Figure 3}

Expression of $E R \alpha$ and $E R \beta$ mRNAs in human thyrocytes and thyrospheres. (A) RT-PCR analysis of the expression of $E R \alpha$ and $E R \beta$ mRNAs, with the expected amplicon sizes of 243 and 112 bp respectively. MCF-7 human breast cancer cells were used as a positive control and GAPDH as an internal control. (B) Results of quantitative real-time PCR. A significantly higher expression of $E R \alpha$ was observed in the thyrospheres. The $\mathrm{Ct}$ value of the real-time RT-PCR was calculated by the $(2 \times \text { efficiency })^{-\Delta \Delta C t}$ method and normalized by the value of the internal control GAPDH. Data are presented as the mean of fold change \pm s.E.M. vs the control, and they were derived from three independent experiments $(* * * P<0.01)$.

Published by Bioscientifica Ltd. 

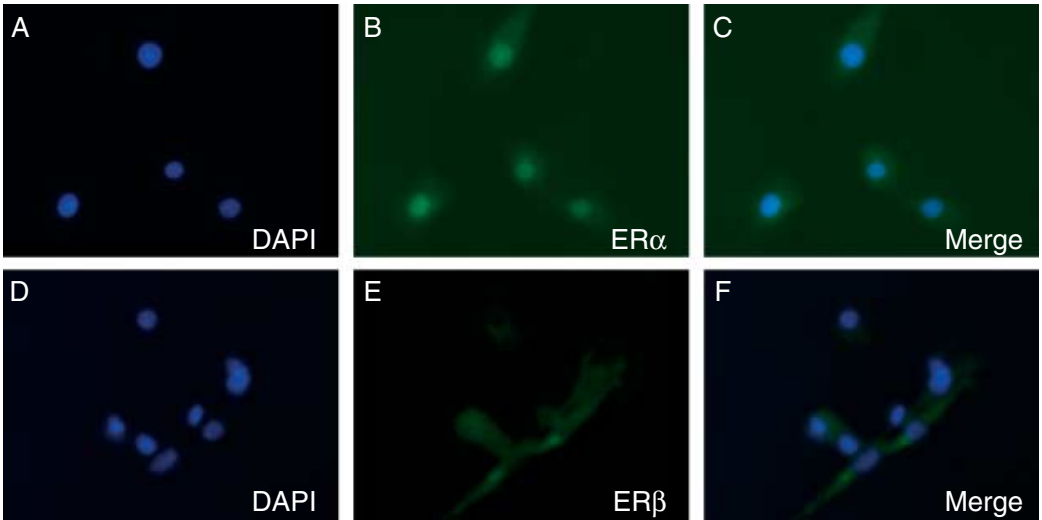

\section{Figure 4}

Localization of $E R \alpha$ and $E R \beta$ in human thyroid stem/progenitor cells by immunofluorescence staining. In human thyroid stem/progenitor cells, both $E R \alpha$ and $E R \beta$ were observed, with $E R \alpha$ being mainly localized in the

\section{Discussion}

There is a large body of evidence that suggests that oestrogen is involved in the pathogenesis of thyroid nodules and differentiated thyroid cancer cells (Santin \& Furlanetto 2011). Oestrogen exerts its effect via genomic and non-genomic signalling (Manole et al. 2001). It controls the central signalling pathways of thyroid growth regulation such as MAP kinase and PI3 kinase pathways (Manole et al. 2001, Zeng et al. 2007, Antico-Arciuch et al. 2010). In tissues derived from human nodular goitres, it has been demonstrated that $\mathrm{E}_{2}$ stimulated the growth of thyroid cells derived from female and male glands to the same extent (Manole et al. 2001). In line with this finding, no common genetic variants in sex hormone pathway genes that may explain the higher incidence rates of proliferative thyroid diseases in females have been detected yet (Schonfeld et al. 2012). Another argument for a pathogenetic role of oestrogen is the increasing incidence of differentiated thyroid cancer in females but not in males with the onset of puberty and the simultaneous rise in the levels of sex hormones (Farahati et al. 1997).

In the present work, we demonstrated that not only mature thyrocytes but thyroid-derived stem and progenitor cells also expressed ERs (Fig. 3A). The proof for the presence of ERs in stem cells comes from the finding that $\mathrm{E}_{2}$ stimulation under starvation conditions, i.e. in a serumfree medium, results in the formation of thyrospheres, although the size of the spheres is smaller than that of those generated in the presence of EGF and bFGF (Fig. 1) or in response to insulin and IGF1 and IGF2 stimulation nucleus and $E R \beta$ in the perinuclear region of the cytoplasm. (A, B and $C$ ), $E R \alpha ;(D, E$ and $F), E R \beta$ in the stem/progenitor cells.

(Malaguarnera et al. 2011, Chen et al. 2012). Spheres including thyrospheres are derived from a single stem cell that generates a self-copy of itself and differentiates into progenitor cells (Lan et al. 2007, Deleyrolle \& Reynolds 2009).

In comparison with primary thyroid cells, thyroid stem/progenitor cells expressed about eight times higher levels of $E R \alpha$ mRNA (Fig. 3B). A predominant expression of $E R \alpha$ was also observed in other stem and progenitor cells (Hu et al. 2011, Matsubara \& Matsubara 2012). Furthermore, overexpression of $E R \alpha$ was also reported in papillary thyroid carcinomas (Di Vito et al. 2011).

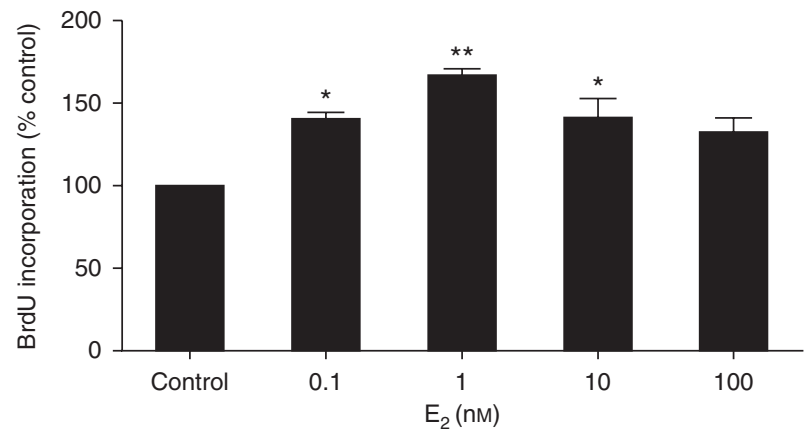

Figure 5

Effects of $E_{2}$ on BrdU incorporation in human thyroid stem/progenitor cells. Secondary passaged thyroid stem/progenitor cells were plated into 96-well microtitre plates pre-coated with poly-L-ornithine/fibronectin in phenol red-free DMEM/F12 medium. The cells underwent starvation and adhesion for $24 \mathrm{~h}$, and they were later incubated with $\mathrm{E}_{2}$ (ranging from 0.1 to $100 \mathrm{nM}$ ) and growth factors for $24 \mathrm{~h}$. BrdU incorporation was measured by BrdU ELISA. Data were derived from three independent experiments conducted with four to six replicates. Results are plotted as the percentage of vehicle controls (mean \pm s.E.M., $* P<0.05$ and $* * P<0.01$ ).

Published by Bioscientifica Ltd. 
A
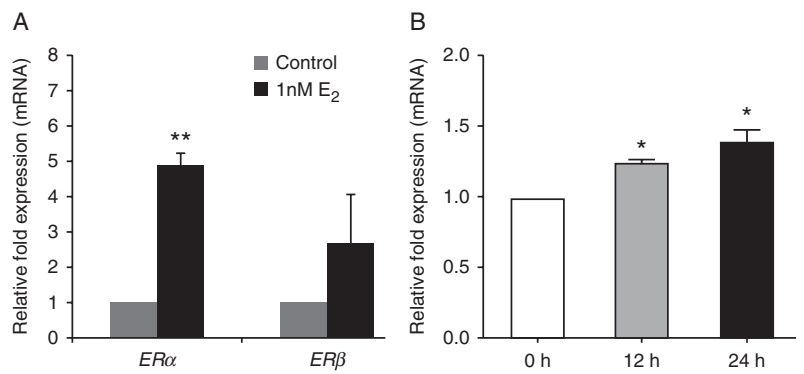

Figure 6

Expression of $E R$ and cyclin D1 mRNAs in thyroid progenitor/stem cells in response to $1 \mathrm{nM} \mathrm{E}_{2}$ stimulation determined by quantitative real-time PCR. (A) Expression of $E R \alpha$ and $E R \beta$ mRNAs in thyroid stem/progenitor cells in response to $1 \mathrm{nM} \mathrm{E}$ stimulation for $24 \mathrm{~h}$. As revealed by the real-time PCR, an almost fivefold increase in the expression of ER $\alpha$ mRNA was observed after incubation with $E_{2}$. No significant change in the expression of $E R \beta$ mRNA was observed. (B) Up-regulation of cyclin D1 mRNA levels induced by $1 \mathrm{nM} \mathrm{E}_{2}$ treatment in thyroid stem/progenitor cells. The $\mathrm{Ct}$ values were calculated by the ( $2 \times$ efficiency $)^{-\Delta \Delta C t}$ method and normalized by the value of the internal control GAPDH. Data are presented as the mean of fold change \pm s.E.M. vs the control, derived from three independent experiments $\left({ }^{*} P<0.05 ; * * P<0.01\right)$.

An increased expression of $E R \alpha$ in highly proliferating stem/progenitor cells, which was further up-regulated by $\mathrm{E}_{2}$ stimulation (Fig. 6), can be explained by the finding that cell growth is primarily regulated via $\mathrm{ER} \alpha$, whereas $E R \beta$ is involved in the control of apoptosis and suppressive functions (Chen et al. 2008). In taking this view, two recent reports that correlated $\mathrm{ER} \alpha$ positivity and loss of ER $\beta$ expression in differentiated thyroid carcinomas with a more aggressive phenotype and a poor outcome are of interest (Heikkila et al. 2012, Magri et al. 2012).

$\mathrm{E}_{2}$ stimulated the proliferation of thyroid stem/ progenitor cells with maximal effect at $1 \mathrm{nM}$ (Fig. 5). In contrast, in primary human thyroid cells, five times higher $\mathrm{E}_{2}$ concentrations and twice the time of stimulation were necessary to achieve maximal growth stimulation (Manole et al. 2001). These differences are attributable to the higher expression levels of $E R \alpha$ in stem/progenitor cells (Fig. 3B) and to the lower proliferation rate of differentiated thyrocytes.

In accordance with the growth-stimulatory effect of $\mathrm{E}_{2}$ on thyroid stem/progenitor cells, the expression of cyclin D1, an important regulator of the cell cycle, whose gene harbours an oestrogen-responsive regulatory region, was up-regulated (Fig. 6B). Similar results were observed before in differentiated human thyroid cells (Manole et al. 2001). In addition, overexpression of cyclin D1 was detected in several papillary thyroid carcinomas (Lazzereschi et al. 1998, Shi et al. 2001, Khoo et al. 2002, Kumar et al. 2010).
Although a large body of reports analysed the effects of oestrogen on benign and malignant thyroid growth, the knowledge on the influence of oestrogen on thyroid differentiation is still very limited. In this work, it has been shown that TSH-induced differentiation was inhibited by $\mathrm{E}_{2}$.

When thyroid progenitor cells were pre-treated with TSH, $\mathrm{E}_{2}$ resulted in a $60-70 \%$ decrease in NIS expression. The inhibitory effect of $\mathrm{E}_{2}$ on the expression of TSHR and TPO mRNAs was significant but substantially lower (Fig. 7). Radio-iodide uptake was not measured, since iodide uptake is absent in a monolayer of progenitor cells (Lan et al. 2007). An inhibitory effect of $E_{2}$ on NIS expression and on radio-iodide uptake was first demonstrated in differentiated FRTL5 rat thyroid cells (Furlanetto et al. 1999, 2001).

Oestrogen action on thyroid stem/progenitor cells, i.e. stimulation of growth and inhibition of differentiation, in particular, of NIS expression, generates a progeny of cells with a higher proliferation rate and a reduced differentiation. Since $\mathrm{E}_{2}$ influences all cells to the same extent, the question arises as to whether all progenitor cells have the same intrinsic growth potential. In the pathogenesis of thyroid nodules and nodular goitres as in many other endocrine and non-endocrine organs, the concept of the heterogeneity of growth and function is generally accepted (Derwahl \& Studer 2002). Each thyroid cell has
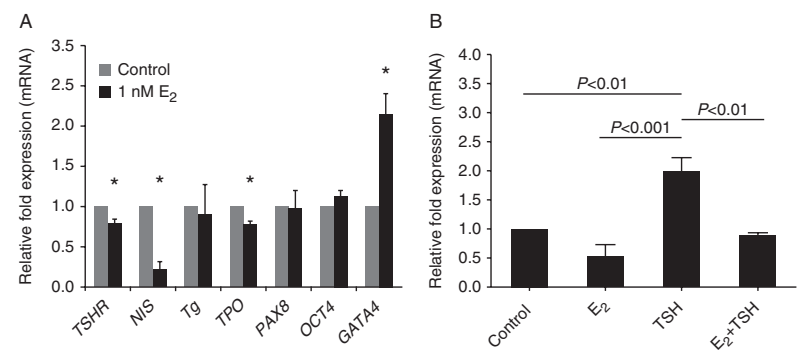

Figure 7

Effect of $E_{2}$ on the expression of the differentiation markers. (A) Effect of $E_{2}$ on TSH-induced differentiation of human thyroid stem/progenitor cells after 3 days of $E_{2}$ stimulation. As revealed by the real-time PCR, the expression of the differentiation markers TSHR, NIS and TPO was significantly decreased, whereas the expression of the endodermal marker GATA4 was increased. Data were derived from three independent experiments. (B) Real-time PCR analysis of the suppressive effect of $E_{2}$ on the expression of NIS mRNA. Human thyroid progenitor/stem cells were cultured with $10 \%$ serum and exposed to $1 \mathrm{nM} \mathrm{E} \mathrm{E}_{2}$ or/and $5 \mathrm{mU} / \mathrm{ml} \mathrm{TSH}$. NIS expression was significantly increased in the TSH-stimulated group. When co-incubated with TSH and $E_{2}$, the up-regulated NIS expression induced by TSH was significantly suppressed by $E_{2}$. Data were derived from four independent experiments. The $C t$ values were calculated by the $(2 \times$ efficiency) ${ }^{-\Delta \Delta C t}$ method and normalized by the value of the internal control GAPDH. Data are presented as the mean of fold change \pm s.E.M. vs the control $(* P<0.05$ and $* * P<0.01)$. http://joe.endocrinology-journals.org DOI: $10.1530 / \mathrm{JOE}-13-0029$
() 2013 Society for Endocrinology Printed in Great Britain 
its individual growth potential and individual function. There is some evidence that heterogeneity may be operative in stem cells also (Collins et al. 2005, Graf \& Stadtfeld 2008). Thus, oestrogen may contribute to the propagation of thyroid progenitor cells with a higherthan-average growth potential and simultaneously decrease their function.

In conclusion, we hypothesize a supportive role of oestrogen in the propagation of thyroid stem/progenitor cells that may lead to the selection of a progeny of growthprone cells with a decreased function. These cells may be the origin of hypofunctioning or non-functioning thyroid nodules in females.

\section{Declaration of interest}

The authors declare that there is no conflict of interest that could be perceived as prejudicing the impartiality of the research reported.

\section{Funding}

This work was supported by a grant from Biomedic e.V. and by IKFE services and supported by Deutsche Forschungsgemeinschaft, Graduierten-Kolleg 1208 (Charite, Berlin).

\section{Acknowledgements}

We are grateful to Diana Nicula and Martina Kleinhardt for their excellent technical support and to Dr D Geipel for providing thyroid tissue samples. In particular, we wish to thank Prof. Josef Köhrle for scientific discussions (Charite, Berlin).

\section{References}

Antico-Arciuch VG, Dima M, Liao XH, Refetoff S \& Di Cristofano A 2010 Cross-talk between PI3K and estrogen in the mouse thyroid predisposes to the development of follicular carcinomas with a higher incidence in females. Oncogene 29 5678-5686. (doi:10.1038/onc.2010.308)

Belfiore A, La Rosa GL, La Porta GA, Giuffrida D, Milazzo G, Lupo L, Regalbuto C \& Vigneri R 1992 Cancer risk in patients with cold thyroid nodules: relevance of iodine intake, sex, age, and multinodularity. American Journal of Medicine 93 363-369. (doi:10.1016/00029343(92)90164-7)

Broecker M, Hammer J \& Derwahl M 1998 Excessive activation of tyrosine kinases leads to inhibition of proliferation in a thyroid carcinoma cell line. Life Sciences 63 2373-2386. (doi:10.1016/S0024-3205(98)00526-8)

Ceresini G, Morganti S, Graiani V, Saccani M, Milli B, Usberti E, Valenti G, Ceda GP \& Corcione L 2006 Estrogen receptor (ER)- $\beta$, but not ER- $\alpha$, is present in thyroid vessels: immunohistochemical evaluations in multinodular goiter and papillary thyroid carcinoma. Thyroid $\mathbf{1 6}$ 1215-1220. (doi:10.1089/thy.2006.16.1215)

Chen GG, Vlantis AC, Zeng Q \& van Hasselt CA 2008 Regulation of cell growth by estrogen signaling and potential targets in thyroid cancer. Current Cancer Drug Targets 8 367-377. (doi:10.2174/ 156800908785133150

Chen G, Xu S, Renko K \& Derwahl M 2012 Metformin inhibits growth of thyroid carcinoma cells, suppresses self-renewal of derived cancer stem cells, and potentiates the effect of chemotherapeutic agents. Journal of Clinical Endocrinology and Metabolism 97 E510-E520. (doi:10.1210/ jc.2011-1754)

Coclet J, Foureau F, Ketelbant P, Galand P \& Dumont JE 1989 Cell population kinetics in dog and human adult thyroid. Clinical Endocrinology 31 655-665. (doi:10.1111/j.1365-2265.1989.tb01290.x)

Collins CA, Olsen I, Zammit PS, Heslop L, Petrie A, Partridge TA \& Morgan JE 2005 Stem cell function, self-renewal, and behavioral heterogeneity of cells from the adult muscle satellite cell niche. Cell 122 289-301. (doi:10.1016/j.cell.2005.05.010)

Dean DS \& Gharib H 2008 Epidemiology of thyroid nodules. Best Practice \& Research. Clinical Endocrinology \& Metabolism 22 901-911. (doi:10.1016/ j.beem.2008.09.019)

Deleyrolle LP \& Reynolds BA 2009 Isolation, expansion, and differentiation of adult mammalian neural stem and progenitor cells using the neurosphere assay. Methods in Molecular Biology 549 91-101. (doi:10.1007/978-1-60327-931-4_7)

Derwahl M 2011 Linking stem cells to thyroid cancer. Journal of Clinical Endocrinology and Metabolism 96 610-613. (doi:10.1210/jc.2010-2826)

Derwahl M \& Studer H 2002 Hyperplasia versus adenoma in endocrine tissues: are they different? Trends in Endocrinology and Metabolism 13 23-28. (doi:10.1016/S1043-2760(01)00519-7)

Di Vito M, De Santis E, Perrone GA, Mari E, Giordano MC, De Antoni E, Coppola L, Fadda G, Tafani M, Carpi A et al. 2011 Overexpression of estrogen receptor- $\alpha$ in human papillary thyroid carcinomas studied by laser-capture microdissection and molecular biology. Cancer Science 102 1921-1927. (doi:10.1111/j.1349-7006.2011.02017.x)

Farahati J, Bucsky P, Parlowsky T, Mader U \& Reiners C 1997 Characteristics of differentiated thyroid carcinoma in children and adolescents with respect to age, gender, and histology. Cancer 80 2156-2162. (doi:10.1002/(SICI)1097-0142(19971201)80:11<2156::AIDCNCR16>3.0.CO;2-Y)

Fierabracci A 2012 Identifying thyroid stem/progenitor cells: advances and limitations. Journal of Endocrinology 213 1-13. (doi:10.1530/ JOE-11-0183)

Fierabracci A, Puglisi MA, Giuliani L, Mattarocci S \& Gallinella-Muzi M 2008 Identification of an adult stem/progenitor cell-like population in the human thyroid. Journal of Endocrinology 198 471-487. (doi:10.1677/JOE-07-0552)

Furlanetto TW, Nguyen LQ \& Jameson JL 1999 Estradiol increases proliferation and down-regulates the sodium/iodide symporter gene in FRTL-5 cells. Endocrinology 140 5705-5711. (doi:10.1210/ en.140.12.5705)

Furlanetto TW, Nunes RB Jr, Sopelsa AM \& Maciel RM 2001 Estradiol decreases iodide uptake by rat thyroid follicular FRTL-5 cells. Brazilian Journal of Medical and Biological Research 34 259-263. (doi:10.1590/ S0100-879X2001000200015)

Gharib H, Papini E \& Paschke R 2008 Thyroid nodules: a review of current guidelines, practices, and prospects. European Journal of Endocrinology 159 493-505. (doi:10.1530/EJE-08-0135)

Graf T \& Stadtfeld M 2008 Heterogeneity of embryonic and adult stem cells. Cell Stem Cell 3 480-483. (doi:10.1016/j.stem.2008.10.007)

Heikkila A, Hagstrom J, Maenpaa H, Louhimo J, Siironen P, Heiskanen I, Haglund C \& Arola J 2013 Loss of estrogen receptor $\beta$ expression in follicular thyroid carcinoma predicts poor outcome. Thyroid $\mathbf{2 3}$ 456-465. (doi:10.1089/thy.2012.0363)

Hu WY, Shi GB, Lam HM, Hu DP, Ho SM, Madueke IC, Kajdacsy-Balla A \& Prins GS 2011 Estrogen-initiated transformation of prostate epithelium derived from normal human prostate stem-progenitor cells. Endocrinology 152 2150-2163. (doi:10.1210/en.2010-1377)

Jarzabek K, Koda M, Kozlowski L, Mittre H, Sulkowski S, Kottler ML \& Wolczynski S 2005 Distinct mRNA, protein expression patterns and distribution of oestrogen receptors $\alpha$ and $\beta$ in human primary breast cancer: correlation with proliferation marker Ki-67 and clinicopathological factors. European Journal of Cancer 41 2924-2934. (doi:10.1016/ j.ejca.2005.09.010) 
Khoo ML, Ezzat S, Freeman JL \& Asa SL 2002 Cyclin D1 protein expression predicts metastatic behavior in thyroid papillary microcarcinomas but is not associated with gene amplification. Journal of Clinical Endocrinology and Metabolism 87 1810-1813. (doi:10.1210/jc.87.4.1810)

Knudsen N, Perrild H, Christiansen E, Rasmussen S, Dige-Petersen H \& Jorgensen T 2000 Thyroid structure and size and two-year follow-up of solitary cold thyroid nodules in an unselected population with borderline iodine deficiency. European Journal of Endocrinology 142 224-230. (doi:10.1530/eje.0.1420224)

Krohn K, Fuhrer D, Bayer Y, Eszlinger M, Brauer V, Neumann S \& Paschke R 2005 Molecular pathogenesis of euthyroid and toxic multinodular goiter. Endocrine Reviews 26 504-524. (doi:10.1210/er.2004-0005)

Kumar A, Klinge CM \& Goldstein RE 2010 Estradiol-induced proliferation of papillary and follicular thyroid cancer cells is mediated by estrogen receptors $\alpha$ and $\beta$. International Journal of Oncology 36 1067-1080. (doi:10.3892/ijo_00000629)

Lan L, Cui D, Nowka K \& Derwahl M 2007 Stem cells derived from goiters in adults form spheres in response to intense growth stimulation and require thyrotropin for differentiation into thyrocytes. Journal of Clinical Endocrinology and Metabolism 92 3681-3688. (doi:10.1210/ jc.2007-0281)

Lazzereschi D, Sambuco L, Carnovale Scalzo C, Ranieri A, Mincione G, Nardi F \& Colletta G 1998 Cyclin D1 and cyclin E expression in malignant thyroid cells and in human thyroid carcinomas. International Journal of Cancer 76 806-811. (doi:10.1002/(SICI) 1097-0215(19980610)76:6 < 806::AID-IJC7 > 3.0.CO;2-1)

Levi BP \& Morrison SJ 2008 Stem cells use distinct self-renewal programs at different ages. Cold Spring Harbor Symposia on Quantitative Biology $\mathbf{7 3}$ 539-553. (doi:10.1101/sqb.2008.73.049)

Libutti SK 2005 Understanding the role of gender in the incidence of thyroid cancer. Cancer Journal 11 104-105. (doi:10.1097/00130404200503000-00003)

Magri F, Capelli V, Rotondi M, Leporati P, La Manna L, Ruggiero R, Malovini A, Bellazzi R, Villani L \& Chiovato L 2012 Expression of estrogen and androgen receptors in differentiated thyroid cancer: an additional criterion to assess the patient's risk. Endocrine-Related Cancer 19 463-471. (doi:10.1530/ERC-11-0389)

Maier J, van Steeg H, van Oostrom C, Karger S, Paschke R \& Krohn K 2006 Deoxyribonucleic acid damage and spontaneous mutagenesis in the thyroid gland of rats and mice. Endocrinology 147 3391-3397. (doi:10.1210/en.2005-1669)

Malaguarnera R, Frasca F, Garozzo A, Giani F, Pandini G, Vella V, Vigneri R \& Belfiore A 2011 Insulin receptor isoforms and insulin-like growth factor receptor in human follicular cell precursors from papillary thyroid cancer and normal thyroid. Journal of Clinical Endocrinology and Metabolism 96 766-774. (doi:10.1210/jc.2010-1255)
Manole D, Schildknecht B, Gosnell B, Adams E \& Derwahl M 2001 Estrogen promotes growth of human thyroid tumor cells by different molecular mechanisms. Journal of Clinical Endocrinology and Metabolism 86 1072-1077. (doi:10.1210/jc.86.3.1072)

Matsubara Y \& Matsubara K 2012 Estrogen and progesterone play pivotal roles in endothelial progenitor cell proliferation. Reproductive Biology and Endocrinology 10 2. (doi:10.1186/1477-7827-10-2)

Mitsutake N, Iwao A, Nagai K, Namba H, Ohtsuru A, Saenko V \& Yamashita S 2007 Characterization of side population in thyroid cancer cell lines: cancer stem-like cells are enriched partly but not exclusively. Endocrinology 148 1797-1803. (doi:10.1210/en.2006-1553)

Rajoria S, Suriano R, Shanmugam A, Wilson YL, Schantz SP, Geliebter J \& Tiwari RK 2010 Metastatic phenotype is regulated by estrogen in thyroid cells. Thyroid 20 33-41. (doi:10.1089/thy.2009.0296)

Reya T, Morrison SJ, Clarke MF \& Weissman IL 2001 Stem cells, cancer, and cancer stem cells. Nature $\mathbf{4 1 4} 105-111$. (doi:10.1038/35102167)

Santin AP \& Furlanetto TW 2011 Role of estrogen in thyroid function and growth regulation. Journal of Thyroid Research 2011875125. (doi:10.4061/2011/875125)

Schonfeld SJ, Neta G, Sturgis EM, Pfeiffer RM, Hutchinson AA, Xu L, Wheeler W, Guenel P, Rajaraman P, de Vathaire F et al. 2012 Common genetic variants in sex hormone pathway genes and papillary thyroid cancer risk. Thyroid 22 151-156. (doi:10.1089/thy.2011.0309)

Shi Y, Zou M, Varkondi E, Nagy A, Kozma L \& Farid NR 2001 Cyclin D1 in thyroid carcinomas. Thyroid 11 709-710. (doi:10.1089/ 105072501750362808)

Studer H \& Derwahl M 1995 Mechanisms of nonneoplastic endocrine hyperplasia - a changing concept: a review focused on the thyroid gland. Endocrine Reviews 16 411-426. (doi:10.1210/edrv-16-4-411)

Thomas T, Nowka K, Lan L \& Derwahl M 2006 Expression of endoderm stem cell markers: evidence for the presence of adult stem cells in human thyroid glands. Thyroid 16 537-544. (doi:10.1089/thy. 2006.16.537)

Todaro M, Iovino F, Eterno V, Cammareri P, Gambara G, Espina V, Gulotta G, Dieli F, Giordano S, De Maria R et al. 2010 Tumorigenic and metastatic activity of human thyroid cancer stem cells. Cancer Research 70 8874-8885. (doi:10.1158/0008-5472.CAN-10-1994)

Zeng Q, Chen GG, Vlantis AC \& van Hasselt CA 2007 Oestrogen mediates the growth of human thyroid carcinoma cells via an oestrogen receptor-ERK pathway. Cell Proliferation 40 921-935. (doi:10.1111/ j.1365-2184.2007.00471.x)

Zheng X, Cui D, Xu S, Brabant G \& Derwahl M 2010 Doxorubicin fails to eradicate cancer stem cells derived from anaplastic thyroid carcinoma cells: characterization of resistant cells. International Journal of Oncology 37 307-315. (doi:10.3892/ijo_00000746)

Received in final form 30 April 2013

Accepted 3 May 2013

Accepted Preprint published online 3 May 2013
(ㄷ) 2013 Society for Endocrinology Printed in Great Britain
Published by Bioscientifica Ltd. 